\title{
Membangun Identitas Budaya Banyumasan melalui Dialek Ngapak di Media Sosial
}

\author{
Ananda Galuh Pawestri \\ Universitas Telkom \\ galuhhtugas@gmail.com
}

How to cite (in APA Style): Pawestri, A.G. (2019). Membangun identitas budaya Banyumasan melalui dialek ngapak di media sosial. Jurnal Pendidikan Bahasa dan Sastra, 19(2), 255-266. DOI: https://doi.org/10.17509/bs_jpbsp.v19i2.24790.

Article History: Received (25 June 2019); Revised (12 August 2019); Accepted (23 September 2019). Journal homepage: http://ejournal.upi.edu./index.php/BS_JPBSP

\begin{abstract}
Abstrak: Dialek ngapak merupakan identitas budaya dari masyarakat Banyumasan yang meliputi kabupaten Banjarnegara, Purbalingga, Banyumas, Cilacap, dan Kebumen. Dialek ngapak memiliki karakteristik pengucapan yang sangat mantap (luged), tegas, lugas, tidak mengambang (ampang) atau setengah-setengah. Penelitian ini menjelaskan bagaimana pemilihan penggunaan dialek ngapak sebagai simbol dari identitas budaya Banyumasan dalam berinteraksi dengan masyarakat Banyumasan lainnya di media sosial. Penelitian ini menggunakan metode kualitatif dengan pendekatan etnografi virtual dan didukung oleh paradigma konstruktivisme. Teknik pengumpulan data yang dilakukan adalah observasi, wawancara, dan dokumentasi sebagai data primer serta studi literatur sebagai data sekunder. Hasil penelitian menunjukkan bahwa dialek ngapak merupakan pengembangan dari pemikiran atau persepsi mengenai stereotype yang ada terhadap dialek ngapak itu sendiri. Persepsi komunitas budaya Banyumasan mengenai dialek ngapak yang merupakan identitas budaya Banyumasan yaitu unik, keren, dan kaya dan memiliki potensi jika dikembangkan. Komunitas budaya Banyumasan menggunakan dialek ngapak sebagai konten dengan tema komedi. Refleksi tersebut merupakan karakter dari wong Banyumasan yaitu cablaka dan mbanyol. Cablaka adalah apa adanya dan mbayol adalah bertingkah konyol atau lucu.
\end{abstract}

Kata kunci: identitas budaya; media sosial; etnografi; budaya banyumasan; dialek ngapak

\section{Building Banyumasan Cultural Identity through The Ngapak Dialect on Social Media}

\begin{abstract}
Ngapak dialect is a cultural identity from Banyumasan area which includes Banjarnegara, Purbalingga, Banyumas, Cilacap, and Kebumen regency. The Ngapak dialect has a unique pronunciation that is assertive (luged) and without a doubt (ampang). This research explains how the ngapak dialect was chosen as a symbol of the Banyumasan's cultural identity to interacting on social media. This research uses a qualitative method with a virtual ethnographic approach and also supported by the constructivism paradigm. The data was collected by observation, interviews, and documentation as the primary data and literature studies as the secondary data. The results of this research are ngapak dialect is the development of the perceptions of the stereotypes with the ngapak dialect that exist and the dialect of ngapak itself. The perception of the Banyumasan cultural community regarding the Ngapak dialect is unique, cool, and rich and has potential. Banyumasan cultural community uses dialect ngapak as content with comedy themes. The reflection of the comedy itself is the character of the Banyumasan folks called cablaka and mbanyol. Cablaka means pure and mbayol means silly or funny.

Keywords: cultural identity; social media; ethnographic; banyumasan culture; ngapak dialect
\end{abstract}




\section{PENDAHULUAN}

Indonesia merupakan negara kepulauan dengan wilayah yang terdiri dari pulau-pulau. Indonesia memiliki pulau sebanyak 17.504 pulau dengan 16.056 pulau diantaranya telah dibakukan dan disubmisi ke PBB (Badan Informasi Geospasial, 2018). Pulau-pulau terbesar yang ada di wilayah Indonesia dintaranya yaitu: Pulau Kalimantan, Pulau Papua, Pulau Sumatera, Pulau Jawa, Pulau Sulawesi, Kepulauan Maluku, Kepulauan Riau, Kepulauan Mentawai, Pulau Halmahera, Pulau Sunda, Pulau Timor, Pulau Madura, Pulau Bali dan Pulau Biak. Dengan bentuk geografis Indonesia yang terdiri dari berbagai macam kepulauan tersebut membuat Indonesia memiliki beragam suku dan budaya.

Keberagaman suku dan budaya di Indonesia dapat dilihat dengan banyak jumlah suku budaya yang ada. Banyaknya suku dan budaya ini membuat Indonesia dikenal dengan Negara multikultural atau majemuk. Menurut Koentjaraningrat (1979,p.21-34), bahwa watak majemuk secara sosio-kultural masyarakat Indonesia adalah terdiri atas bangsa yang bersuku-suku dengan cara hidup bermasyarakat dan berbudaya, adat istiadat serta 300 lebih dialek lokal, hidup diatas lebih kurang 17 ribu pulau-pulau yang membentang dari Sabang ke Merauke serta dari Zulu ke Pulau Rote. Namun, keberagaman ini dapat disatukan dengan adanya pancasila sebagai ideologi bangsa Indonesia dengan semboyan "Bhinneka Tunggal Ika" yang memiliki arti walau berbeda-beda tetapi tetap satu jua.

Kebudayaan adalah keseluruhan sistem gagasan, tindakan, dan hasil karya manusia dalam rangka kehidupan masyarakat yang dijadikan milik diri manusia dengan belajar (Koentjaraningrat, 1979, p.72). Kemudian, kebudayaan sendiri memiliki tujuh unsur menurut Koentjaraningrat (1979, p.203), yaitu: religi, kesenian, sistem kemasyarakatan, peralatan dan perlengkapan hidup dan bahasa. Kebudayaan terbentuk dari adat istiadat yang ada di masyarakat Indonesia sehingga setiap suku memiliki kebudayaannya sendiri. Kebudayaan merupakan salah satu harta yang dimiliki
Indonesia dan setiap kebudayaan dari beragam suku yang ada di Indonesia merupakan warisan leluhur yang perlu dilestarikan.

Secara etimologis, kata identitas berasal dari kata identity, yang berarti (1) kondisi atau kenyataan tentang sesuatu yang sama, suatu keadaan yang mirip satu sama lain, (2) kondisi atau fakta tentang sesuatu yang sama di antara dua orang atau dua benda, (3) kondisi atau fakta yang menggambarkan sesuatu yang sama diantara dua orang (individualitas) atau dua kelompok atau benda, (4) pada tataran teknis, pengertian etimologis di atas hanya sekedar menunjukan suatu kebiasaan untuk memahami identitas dengan kata 'identik'(Webster New World Dictionary dalam Darmastuti, 2013,p.94).

Identitas budaya (Liliweri, 2002, p.9596) merupakan ciri yang muncul karena seseorang itu merupakan anggota dari sebuah kelompok etnik tertentu. Itu meliputi pembelajaran tentang dan penerimaan tradisi, sifat bawaan, bahasa, dan keturunan dari suatu kebudayaan. Menurut Ting-Toomey (Darmastuti, 2013, p.94), identitas budaya atau kultural merupakan perasaan (emotional significance) dari seseorang untuk ikut memiliki (sense of belonging) atau berafiliasi dengan kultur tertentu. Masyarakat yang terbagi kedalam kelompok-kelompok itu kemudian melakukan identifikasi kultural (cultural identification), yaitu masing-masing orang mempertimbangkan diri mereka sebagai representasi dari sebuah budaya partikular.

Istilah kebudayaan hampir selalu terikat pada batas fisik yang jelas berupa daerah secara geografis. Ruang budaya Jawa Tengah merupakan pulau Jawa, namun secara administratif, Jawa dibagi dalam beberapa provinsi. Dalam ruang budaya Jawa Tengah, terbagi dalam tiga subkultur ranah budaya. Pertama ranah keraton (atau sering disebut sub-kultur nagaragung). Kedua, ranah budaya Banyumasan (subkultur dulangmas). Dan ketiga, subkultur pesisir yaitu pesisir wetan, Kedu dan sekitarnya (Sujatmo, 1992, dalam Trianton, 2013,p.14).

Bahasa dalam kajian kebudayaan disebut sebagai alat atau perwujudan 
budaya yag digunakan manusia untuk saling berkomunikasi atau berhubungan. Bahasa merupakan pilihan krusial terjadinya ketersalingan pemahaman antarmanusia. Bahasa dapat disampaikan melalui tulisan, lisan, maupun gerakan isyarat atau gesture (Putra, 2016,p.43). Bahasa merupakan alat penyampaian pesan kepada orang lain, oleh Chaer (1994, p.71-81) membedakan jenis-jenis atau klasifikasi bahasa menjadi empat diantaranya:

1. Pendekatan genetis yaitu bahasa yang diturunkan secara genealogis (berdasarkan keturunan)

2. Klasifikasi tipologi yaitu berdasarkan kesamaan tipe bahasa seperti bunyi, morfem, kata, frase, kalimat, dan sebagainya

3. Klasifikasi areal yaitu berdasarkan hubungan timbal balik antar bahasa dalam suatu areal atau wilayah, tanpa memperhatikan apakah bahasa itu berkerabat secara genetika atau tidak

4. Klasifikasi sosiolinguistik yaitu berdasarkan hubungan bahasa dengan status, fungsi, penilaian yang diberikan masyarakat terhadap bahasa itu.

Bahasa suatu masyarakat terdiri dari ragam bahasa berdasar letak geografis masing-masing. Ragam bahasa dalam geografis kecil disebut dengan dialek atau logat. Istilah tersebut oleh masyarakat bahasa yang besar memiliki nilai yang merendahkan. Orang yang memakai bahasa besar atau bahasa baku dalam kehidupan sehari-hari cenderung menganggap rendah orang-orang yang menggunakan dialek atau logat (Anwar, 1990,p.33-34).

Salah satu suku terbesar yang ada di Indonesia adalah suku Jawa. Suku Jawa tersebar pada hampir seluruh wilayah yang ada di Indonesia hingga populasinya mencapai 40 persen dari populasi penduduk Indonesia (BPS, 2018). Suku Jawa paling banyak menempati wilayah Pulau Jawa seperti di Jawa Timur, Jawa Tengah, dan Yogyakarta Suku Jawa memiliki beragam jenis kebudayaan. Salah satu kebudayaannya adalah bahasa dan dialek. Dialek tersebutlah yang nantinya menjadi identitas budaya penanda asal suku Jawa berasal karena pada setiap daerah memiliki ciri khas dialek masing-masing ketika menggunakan bahasa Jawa. Bahasa Jawa memiliki suatu sistem tingkatan. Tingkatan tersebut mengenai perbedaan umur, kedudukan atau status sosial, dan keakraban. Bahasa ini diantaranya adalah Krama, digunakan ketika berbicara dengan orang yang usianya lebih tua dari kita, status sosialnya lebih tinggi dari kita, atau orang asing yang baru kita temui. Kemudian ada Ngoko yang digunakan ketika berbicara dengan teman sebaya.

Salah satu bahasa dan dialek dari suku Jawa yaitu dialek ngapak yang merupakan kebudayaan yang berasal dari daerah Banyumasan. Banyumas merupakan nama suatu daerah di bagian barat daya wilayah pulau Jawa bagian tengah. Wilayah Banyumas yang dimaksud adalah wilayah yang secara administrasi mulai 1 Januari 1936 merupakan wilayah bekas karesidenan yang terdiri dari empat kabupaten, yaitu Banjarnegara, Purbalingga, Banyumas, Cilacap (Herusatoto, 2008,p.4). Disebut bahasa Jawa ngapak karena pengucapan vokal a dan o, konsonan b, d, k, g, h, y, k, l, dan w, sangat mantap (luged), tegas, lugas, tidak mengambang (ampang) atau setengahsetengah, seperti yang diajarkan di sekolah formal yang disebut bahasa Jawa baku (Herusatoto, 2008,p.6-7).

Saat ini dialek ngapak mulai mengalami pergeseran. Salah satu faktor adanya pergeseran tersebut adalah adanya sterotype terhadap dialek ngapak, menurut hasil penelitian Susmono (2006 dalam Khotimah, 2017) diperoleh kesimpulan bahwa para mahasiswa Cilacap yang merupakan salah satu kelompok masyarakat penutur dialek ngapakdi Yogyakarta secara psikologis merasa terganggu dengan stereotype bahasa dan budaya ngapakyang dianggap marjinal sehingga mereka enggan menggunakan dialek tersebut. Masyarakat Banyumas sering digambarkan sebagai kelompok marginal dalam budaya Jawa secara umum. Dalam posisi marginal, masyarakat Banyumas merasa bangga dengan kebudayaan yang dimilikinya, tetapi di sisi lain, mereka merasa 
inferior, terutama jika dibandingkan dengan kebudayaan di Jogjakarta dan Surakarta yang dianggap secara luas sebagai bentuk asli karakter Budaya Jawa. Banyumas yang dianggap sebagai daerah "pinggir", secara politis dan budaya dianggap tidak mempunyai karakter budaya tinggi yang bisa duduk sejajar dengan kesenian di keraton Jogjakarta dan Surakarta (Santosa, 2015).

Media sosial adalah medium di internet yang memungkinkan pengguna mempresentasikan dirinya maupun berinteraksi, bekerja sama, berbagi, berkomunikasi dengan pengguna lain, dan membentuk ikatan sosial secara virtual (Nasrullah, 2015,p.11). Media sosial adalah fitur berbasis website yang dapat membentuk jaringan serta memungkinkan orang untuk berinteraksi dalam sebuah komunitas. Pada sosial media kita dapat melakukan berbagai bentuk pertukaran, kolaborasi dan saling berkenalan dalam bentuk tulisan visual maupun audiovisual. Contohnya seperti Twitter, Facebook, Blog, Forsquare dan lainnya. (Puntoadi, 2011,p.).

Manfaat sosial media menurut Puntoadi (2011,p.19) adalah menentukan personal branding yang diinginkan, mencari lingkungan yang tepat, mempelajari cara berkomunikasi, untuk konsistensi dan sebagai Mix the media. Fantastic marketing result through Social media: "people don't watch TV's anymore, they watch their mobile phones".Media Sosial memberikan kesempatan untuk berinteraksi lebih dekat dengan konsumen, dapat menjadi media untuk membentuk komunitas online. Sosial media dapat menjadi bagian dari keseluruhan e-marketing strategy yang digabungkan melalui sosial media lain. Serta sebagai jalan menemukan menciptakan para brand evangelist. Sosial media memberikan peluang masuk komunitas yang telah ada sebelumnya dan memberikan kesempatan mendapatkan feedback secara langsung (Puntoadi, 2011,p.21-31).

Salah satu cara untuk dapat melestarikan kebudayaan adalah dengan memanfaatkan Internet. Internet atau interconnection networking merupakan sebuah teknologi yang dapat menghubungkan antar komputer untuk bisa saling berkomunikasi.
Perkembangan Internet di Indonesia sendiri sudah semakin berkembang, saat ini sudah semakin banyak masyarakat Indonesia yang menggunakan dan memanfaatkan teknologi Internet seiring dengan banyaknya pembangunan infrastruktur di wilayah Indonesia.

Berdasarkan penelitian yang dilakukan oleh We Are Social yang bekerjasama dengan Hootsuite, ditemukan bahwa dari populasi masyarakat Indonesia yaitu sejumlah 265,4 juta jiwa, sebanyak 132,7 juta jiwa telah menggunakan Internet dan sebanyak 130 juta jiwa merupakan pengguna aktif di sosial media. Hal ini menunjukan bahwa sekitar 97,9\% pengguna Internet di Indonesia sudah menggunakan media sosial. Kemudian jika dibandingkan dengan total penduduk Indonesia, ini menunjukan bahwa $48 \%$ penduduk Indonesia telah menggunakan media sosial (We Are Social, 2018).

Menurut Van Dijk dalam Nasrullah (2015,p.11) media sosial adalah platform media yang memfokuskan pada eksistensi pengguna yang memfasilitasi mereka dalam beraktivitas maupun berkolaborasi. Karena itu, media sosial dapat dilihat sebagai medium (fasilitator) online yang yang menguatkan hubungan antarpengguna sekaligus sebagai sebuah ikatan sosial. Pengertian media sosial singkatnya merupakan media yang dapat digunakan untuk berkomunikasi seperti berbagi dan memperoleh informasi. Masyarakat pun bebas memilih jenis informasi yang ingin mereka peroleh dan bagi. Contoh dari media sosial yang banyak diminati saat ini adalah Instagram, Youtube, Twitter dan Facebook.

Berdasarkan uraian di atas peneliti tertarik untuk mengkaji bagaimana pemilihan penggunaan dialek ngapak sebagai simbol dari identitas budaya Banyumasan dalam berinteraksi dengan masyarakat dengan mengambil tema penelitian "Membangun Identitas Budaya Banyumasan Melalui Dialek Ngapak di Media Sosial".

\section{METODE}

Penelitian ini menggunakan metode kualitatif yang pada dasarnya merupakan cara ilmiah 
untuk mendapatkan data dengan tujuan dan kegunaan tertentu. Berdasarkan hal tersebut terdapat empat kata kunci yang perlu diperhatikan yaitu cara ilmiah, data, tujuan dan kegunaan (Sugiyono, 2015). Penelitian kualitatif menekankan pada quality atau hal terpenting suatu kejadian, fenomena, dan gejala sosial adalah makna dibalik kejadian tersebut yang dapat dijadikan pelajaran berharga bagi pengembangan konsep teori. Penelitian kualitatif dapat didesain untuk memeberikan sumbangannya terhadap teori, praktis, kebijakan, masalah-masalah sosial, dan tindakan. Penelitian kualitatif dieksplorasi dan diperdalam dari fenomena sosial atau lingkungan sosial yang terdiri atas pelaku, kejadian, tempat, dan waktu (Ghony \& Almanshur, 2012,p.25). Penelitian ini menggunakan pendekatan kualitatif untuk memahami fenomena mengenai identitas budaya ngapak yang dibangun oleh komunitas masyarakat budaya Banyumasan di media sosial.

Pendekatan yang digunakan dalam penelitian ini adalah etnografi virtual. Sebagai suatu kultur dan artefak kultural, cyberspace atau dunia siber bagi peneliti etnografi virtual bisa mendekati beberapa objek atau fenomena yang ada di internet. Identitas, komunitas, dan perkembangan teknologi Internet memang merupakan isu utama yang sering dibahas saat ini. Etnografi virtual merupakan metode etnografi yang dilakukan untuk melihat fenomena sosial dan atau kultur pengguna di ruang siber (Nasrullah, 2015, p.171-172).

Dalam penelitian menggunakan pendekatan etnografi virtual ini maka peneliti melakukan beberapa hal berikut ini:

1. Halaman situs dalam penelitian ini merupakan media sosial Instagram(http:instagram.com) dan Youtube (http:youtube.com) yang peneliti akses melalui web maupun aplikasi.

2. Dari dua media sosial tersebut peneliti menemukan beberapa akun media sosial yang menggunakan dialek ngapak sebagai konten, kemudian peneliti mengikuti akun media sosial tersebut.
3. Melakukan pengamatan terhadap gambaran umum mengenai konten, aktivitas dalam penggunaan fitur yang ada di media sosial, dan interaksi yang terjadi melalui fitur yang disediakan oleh media sosial tersebut.

4. Peneliti menghubungi pemilik akun media sosial dan melakukan wawancara untuk memverifikasi informasi yang diberikan dan memastikan kehidupan offline subjek.

5. Peneliti juga melakukan penelusuran terhadap budaya Banyumasan terutama dalam penggunaan dialek ngapak melalui penelitian terdahulu dan buku untuk melihat penggambaran mengenai dialek ngapak.

\section{HASIL DAN PEMBAHASAN}

Wilayah Budaya Banyumasan dan wong Banyumas

Wong Banyumas atau komunitas Jawa Banyumasan dikenal berbeda dengan masyarakat Jawa lainnya dengan ciri khas dialek ngapak yang dimiliki. Komunitas Banyumasan saat ini menempati wilayah barat daya Jawa Tengah. Secara historis. Etnologis, sosiologis, kultural, dan formal disebut wilayah Barlingmascakeb yang meliputi Banjarnegara, Purbalingga, Banyumas, Cilacap dan Kebumen. Wilayah tersebut disebut sebagai kesatuan wilayah pembangunan Barlingmascakeb yang berkantor di Purwokerto (Herusatoto, 2008,p.6).

\section{Komunitas Budaya Banyumasan Dialek Ngapak di Media Sosial}

Perkembangan internet di Indonesia tak terkecualikan bagi komunitas budaya Banyumasan. Masyarakat tidak ketinggalan dan ikut larut dalam penggunaan internet terutama media sosial. Media sosial menjadi tempat bagi sejumlah komunitas budaya Banyumasan untuk berkiprah dan tempat bertemu dengan masyarakat terutama masyarakat Banyumasan lainnya. Komunitas budaya Banyumasan memanfaatkan media 
sosial yaitu instagram dan youtube dalam menunjukan identitasnya.

\section{a. Koplak Story}

Koplak Story merupakan salah satu komunitas Budaya Banyumasan yang dibentuk mulai tahun 2015 dan diprakasai oleh Jibrot dan Bontot. Nama Koplak Story sendiri memiliki arti cerita koplak atau cerita lucu. Namun, menurut Jibroth salah satu pendiri Koplak Story, nama Koplak tersebut sebenarnya merupakan akronim yang memiliki arti Cerita Kumpulan Orang Purwokerto Lucu dan Kreatif.

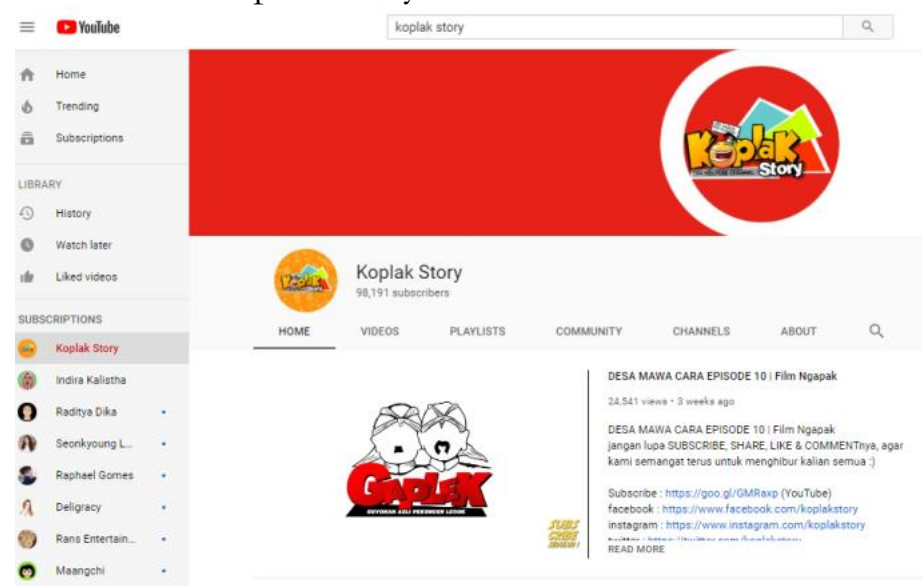

(Sumber: www.youtube.com, diakses pada tanggal 18 Maret 2019 pukul 14.15)

Media sosial utama yang digunakan oleh Koplak Story adalah youtube. Youtube Koplak Story telah memiliki 98.191 subscribers. Koplak Story juga berhasil terpilih dalam 12 channel youtube yang memenangkan youtube next up dari 400 orang peserta dengan membuat konten membawa kearifan lokal berupa dialek ngapak Banyumasan. Konten yang dikembangkan oleh Koplak Story merupakan webseries dengan genre komedi. b. Niki Kula

Awal pembuatan akun media sosial Niki Kula berawal dari media sosial pribadi (a)alanasprila. Kemudian semakin viralnya video-video yang dibuat oleh Alan Asprila, media sosial instagram dengan nama @ guyonbanyumasan yang kemudian berganti nama menjadi@nikikula. Niki Kula memiliki arti ini saya. Dengan adanya akun media sosial tersebut mas Alan ingin menunjukan ini identitas Banyumasan.
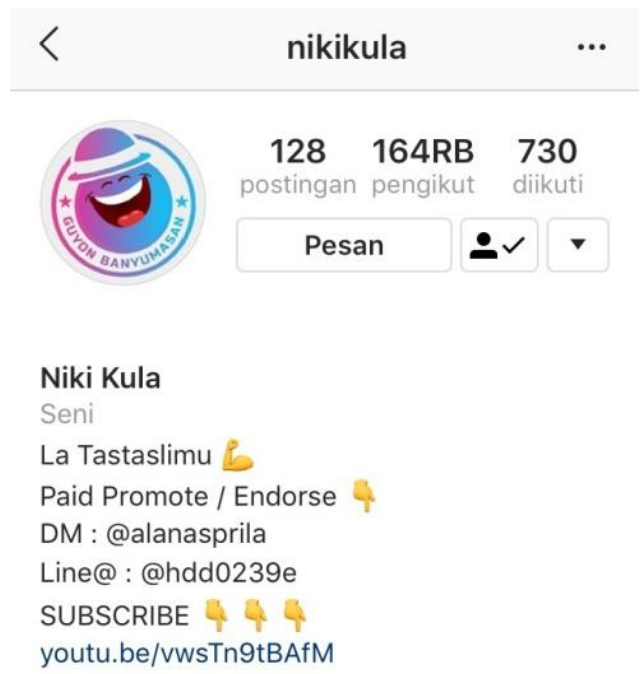

(Sumber: www.instagram.com, diakses pada tanggal 18 Maret 2019 pukul 18.36) 
Media sosial utama instagram Niki Kula telah memiliki followers sebanyak 164.000. Konten yang dikembangkan oleh Niki Kula merupakankonten komedi seperti plesetan akronim nama daerah yang ada di wilayah Banyumasan dan \#YhaChallenge.

\section{Identitas budaya Banyumasan melalui dialek ngapak di media sosial}

Menurut Ting-Toomey (Darmastuti, 2013: 94), identitas budaya atau kultural merupakan perasaan (emotional significance) dari seseorang untuk ikut memiliki (sense of belonging) atau berafiliasi dengan kultur tertentu. Masyarakat yang terbagi kedalam kelompok-kelompok itu kemudian melakukan identifikasi kultural (cultural identification), yaitu masing-masing orang mempertimbangkan diri mereka sebagai representasi dari sebuah budaya particular.

Identitas budaya yang muncul oleh komunitas Banyumasan di media sosial karena adanya perasaan (emotional significance) dari seseorang untuk ikut memiliki (sense of belonging) atau berafiliasi dengan kultur tertentu. Mas Jibroth dari Koplak Story dan mas Alan dari Niki Kula memiliki perasaan sense of belonging karena mereka merupakan keturunan atau trah wong Banyumas yang mengakui memiliki kakeknenek moyang (leluhur) orang Banyumas. Kemudian mas Bontot dari Koplak Story memiliki perasaan sense of belonging karena mas Bontot telah tinggal di Purwokerto yang merupakan salah satu wilayah budaya Banyumasan selama sepuluh tahun sebagai tanah perantauan dan jatuh cinta pada kehidupan sosial-budaya, logat bahasa, dan merasa nyaman bergaul dengan wong Banyumas lainnya yang juga tinggal bersama. Kemudian mereka melakukan identifikasi kultural (cultural identification), yaitu mereka menggunakan dialek ngapak sebagai representasi diri mereka untuk menyatakan bahwa mereka merupakan anggota dari kelompok komunitas Banyumasan.

\section{Persepsi terhadap stereotype dan dialek ngapak}

Komunitas Banyumasan dalam menggunakan simbol dialek ngapak yang merupakan identitas budaya Banyumasan dalam interaksi di media sosial merupakan pengembangan dari pemikiran atau persepsi mereka mengenai stereotype yang ada terhadap dialek ngapak dan dialek ngapak itu sendiri. Pemikiran komunitas budaya Banyumasan terhadap simbol dialek ngapak yang merupakan identitas budaya Banyumasan yaitu unik, keren, dan kaya sehingga jangan malu dan berbanggalah karena dialek ngapak memiliki potensi jika dikembangkan sebagai identitas diri.

Komunitas budaya Banyumasan dialek ngapak menggunakan dialek ngapak berkaitan dengan tindakan yang berorientasi pada masa lalu yaitu adanya persepsi yang muncul berupa stereotype (labelisasi) tentang dialek Banyumasan. Dialek ngapak Banyumasan mendapat stereotype terutama dari masyarakat jawa lainnya. Santosa dalam penelitiannya (2015) juga menjelaskan bahwa masyarakat Banyumas sering digambarkan sebagai kelompok marginal dalam budaya Jawa secara umum. Dalam posisi marginal, masyarakat Banyumas merasa bangga dengan kebudayaan yang dimilikinya, tetapi di sisi lain, mereka merasa inferior, terutama jika dibandingkan dengan kebudayaan di Jogjakarta dan Surakarta yang dianggap secara luas sebagai bentuk asli karakter Budaya Jawa. Banyumas yang dianggap sebagai daerah "pinggir", secara politis dan budaya dianggap tidak mempunyai karakter budaya tinggi yang bisa duduk sejajar dengan kesenian di keraton Jogjakarta dan Surakarta. Kemudian juga sering ada anggapan "ayu-ayu kok ngapak" terhadap wanita Banyumasan. Karena dialek ngapak terdengar pating kropyak (seperti suara benturan kayu-kayu kering) dan menjadi bahan ejekan atau tertawaan karena dalam telinga mereka terdengar lucu (Herusatoto, 2008,p.133). Berdasarkan pengalaman mas Alan dalam mengelola akun media sosial yang mengangkat dialek ngapak, terdapat beberapa stereotype terhadap dialek ngapak di kolom komentar media sosial, seperti menanyakan asal dari bahasa dan menganggap dialek ngapak seperti bahasa dari planet.

Namun menurut komunitas budaya Banyumasan, adanya stereotype mengenai 
dialek ngapak adalah pandangan biasa dan tidaklah membuat mereka merasa minder sebagai penutur dialek ngapak Banyumasan. Karena menurut mereka dialek ngapak itu unik dan memiliki potensi bagi penuturnya bila dikembangkan. Dialek ngapak banyak digunakan oleh beberapa artis sebagai identitas dalam panggung mereka seperti contohnya Kartika Putri yang suka melawak menggunakan dialek ngapak.

Pemikiran komunitas Banyumasan terhadap dialek ngapak yaitu unik dan kaya. Menurut mas Bontot yang merupakan bukan orang Banyumas asli dan telah menjadi bagian dari masyarakat Banyumasan karena telah lama hidup berdampingan dan melakukan sosialisasi secara rutin dengan masyarakat Banyumasan, ia memiliki persepsi bahwa dialek ngapak itu unik dan keren serta memiliki ciri khas yaitu jika berbicara munchu-munchu seperti orang yang sedang padhu. Hal tersebut sesuai dengan watak orang Banyumasan yaitu lageyan cowag (bicara dengan nada lugas) menunjukan bahwa tidak ada yang perlu disembunyikan di hati atau dibisik-bisikkan agar orang lain tidak mendengarnya (Herusatoto, 2008,p.181). Namun keunikan tersebutlah yang menimbulkan dialek ngapak memiliki ciri khas sehingga masyarakat Banyumasan mudah teridentifikasi melalui ciri khas identitas dialek ngapak-nya. Identitas masyarakat Banyumasan dapat dilihat dari pengucapan huruf " $a, b, d, g, h, y, k, 1, o, w$ " dengan mantap, tegas, lugas, tidak ngambang atau setengah-setengah (Herusatoto, 2008,p.122).

Kemudian menurut mas Alan, dialek ngapak itu kaya karena memiliki kosa kata yang banyak yang tidak semuanya dapat diartikan ke dalam bahasa nasional atau bahasa Indonesia. Hal ini terkait asal-usul dari dialek ngapak sendiri yang pada mulanya disebut bahasa Jawadipa atau bahasa orangorang yang tinggal di Pulau Jawa.

\section{Representasi identitas budaya dialek ngapak di media sosial}

Komunitas budaya Banyumasan merefleksikan identitas budaya Banyumasan yaitu dialek ngapak melalui konten di media sosial. Refleksi tersebut merupakan karakter dari wong Banyumasan yaitu cablaka dan mbanyol. Cablaka adalah apa adanya dan mbayol adalah bertingkah konyol atau lucu. Komunitas budaya Banyumasan memilih menonjolkan karakteristik tersebut karena pada dasarnya dialek ngapak sendiri juga sudah memiliki karakter lucu.

Candrajiwa wong Banyumasan dapat dikenali dari lageyan atau tingkah laku dan kebiasaan hidup sehari-hari. Lageyan ini menunjukan perbedaan sifat seseorang atau komunitas dengan orang pada komunitas lain. Lageyan wong Banyumasan adalah segala tingkah laku dalam menghadapi berbagai persoalan kehidupan sehari-hari yang dipengaruhi kearifan lokal produk budaya nenek moyang Herusatoto (Trianton, 2013,p.16). Salah satu ciri lageyan wong Banyumasan adalah mbanyol, yaitu suka bertingkah konyol atau lucu dan saling menyindir (Herusatoto, 2008,p.180).

Pengelolaan dengan membuat konten komedi atau dagelan juga merupakan salah satu representasi kebudayaan Banyumasan. Dagelan merupakan salah satu akar tradisi yang menjadi bagian dari watak wong Banyumas. Tradisi ini melengkapi karakter lain, seperti cablaka (transparan), apa adanya, egaliter, dan glogok sor atau suka mengumbar ukara (ucapan). Dalam perkembangannya, dagelan kemudian menjadi salah satu seni tradisional khas Banyumas. Dagelan merupakan salah satu bentuk sastra lisan tertua di Banyumas, disamping seni Dalang Jemblung (Trianton, 2013,p.17).

Refleksi identitas budaya Banyumasan oleh komunitas budaya Banyumasan di media sosial juga digambarkan dalam penggunaan dialek ngapak sebagai nama akun, bahasa dalam konten video, dan penulisan caption. Penggunaan nama akun seperti akronim Koplak yaitu Kumpulan Orang Purwokerto Lucu dan Kreatif dan Niki Kula yang memiliki arti ini saya merupakan menunjukan akun media sosial tersebut merefleksikan dirinya mewakili orang Purwokerto yang merupakan salah satu dari masyarakat Banyumasan. Kemudian penggunaan dialek ngapak dalam konten 
video dan penulisan caption juga merefleksikan akun media sosial tersebut merupakan komunitas Banyumasan karena penggunaan dialek ngapak yang merupakan identitas budaya dari masyarakat Banyumasan.

\section{Komunitas Virtual Banyumasan di Media Sosial}

Masyarakat Banyumasan yang aktif menggunakan internet dan saling terhubung melakukan interaksi di media sosial akan membentuk komunitas virtual. Menurut Tim Jordan (1999) dalam Nasrullah, 2014,p.149) ruang siber tempat dimana sejumlah pengguna bertemu dalam ruang informasi yang sama. Bahwa pengguna tidak lagi beranggapan bahwa mereka sendiri di ruang siber, sebaliknya pengguna itu bisa membangun relasi dengan para pengguna lainnya. Komunitas budaya Banyumasan seperti Koplak Story dan Niki Kula telah membangun wadah bagi masyarakat Banyumasan pengguna sosial media untuk saling bertemu dan menikmati konten komedi yang mereka buat. Masyarakat Banyumasan yang berkumpul dan berinteraksi melalui komentar terhadap postingan konten Koplak Story atau Niki Kula dan mengikuti mereka di media sosial telah membentuk komunitas virtual Banyumasan di media sosial. Mereka dapat melakukan pencarian dengan menggunakan hastag seperti wilayah budaya Banyumasan \#Purwokerto \#Banjarnegara \#Kebumen \#Cilacap \#Purbalingga \#Banyumas untuk menemukan satu sama lain.

Koplak Story melalui mas Jibroth menyatakan bahwa penggunaan dialek ngapak pada kontennya ingin menunjukkan bahwa dengan membawa kearifan lokal salah satunya dialek ngapak Banyumasan dapat menghasilkan prestasi. Kemudian juga ingin membangkitkan rasa bangga masyarakat Banyumasan terhadap dialek ngapak sehingga tidak minder lagi dengan adanya stereotype. Hal ini sesuai dengan fungsi komunikasi masa yaitu motivasi, komunikasi massa berfungsi menjelaskan tujuan setiap masyarakat jangka pendek maupun jangka panjang, mendorong orang untuk menentukan pilihannya dan keinginannya. Dalam hal ini komunitas budaya Banyumasan ingin mendorong masyarakat untuk terus bangga dan berani menunujukan identitas budaya Banyumasan melalui dialek ngapak. Kemudian tujuan tersebut juga berhubungan dengan fungsi komunikasi massa yaitu memajukan kebudayaan, komunikasi massa berfungsi sebagai penyebarluasan hasil kebudayaan dan seni dengan maksud melestarikan masa lalu, perkembangan kebudayaan. Adanya konten dengan penggunaan dialek ngapak di media sosial dapat turut mengenalkan identitas budaya Banyumasan melalui dialek ngapak di media sosial dan juga sebagai salah satu upaya untuk pelestarian penggunaan dialek ngapak bagi para penuturnya.

Bagi Niki Kula menurut mas Alan sendiri alasan menggunakan dialek ngapak karena dari awal dia membuat konten di media sosial target audiens utamanya adalah untuk orang Banyumasan sehingga menggunakan dialek ngapak agar lebih mudah diterima dan dialek ngapak yang memiliki karakter bahasa lucu mendukung dengan konten komedi yang dibuat di media sosial dan bisa menghibur. Hal ini sesuai dengan fungsi komunikasi masa yaitu hiburan, komunikasi massa berfungsi sebagai penyebarluasan sinyal, simbol, suara dan citra dari drama tari, musik, olahraga dan sebagainya untuk hiburan kelompok atau individu. Dalam hal ini komunitas budaya Banyumasan ingin menyediakan hiburan bagi masyarakat Banyumas melalui konten komedi yang dibuat berdasarkan karakter cablaka dan mbayol yang dekat dengan karakter wong Banyumasan. Kemudian tujuan tersebut juga berhubungan dengan fungsi komunikasi massa yaitu integrasi, komunikasi massa berfungsi menyediakan bagi bangsa, kelompok atau individu untuk memperoleh berbagai pesan yang diperlukan agar dapat saling kenal dan mengerti menghargai kondisi, pandangan dan keinginan orang lain. Dengan target audiens masyarakat Banyumasan, komunitas Budaya Banyumasan menjadikan akun media sosial mereka sebagai wadah untuk tempat 
bertemunya warga Banyumasan dan menyatukan mereka.

\section{Pengelolaan Media Sosial}

Komunitas budaya Banyumasan telah melalukan pemanfaatan media digital dengan mengangkat potensi ciri khas identitas budayanya yaitu dialek ngapak menjadi sebuat konten video yang dapat menghibur masyarakat dan menyebarkannya melalui media sosial. Dalam melakukan hal tersebut komunitas budaya Banyumasan mengelola akun media sosialnya dengan berbagai strategi, yaitu:

\section{a. Pemilihan dan Penggunaan Media Sosial \\ Media sosial yang dipilih oleh} komunitas budaya Banyumasan adalah Youtube dan instagram. Youtube dipilih karena Youtube sangat mendukung konten kreator untuk terus berkembang dan dapat menghasilkan uang. Selain itu, berdasarkan penelitian yang dilakukan oleh We Are Social yang bekerjasama dengan Hootsuite menunjukan platform media sosial yang paling banyak digunakan dan dikunjungi oleh masyarakat Indonesia adalah Youtube dengan jumlah presentase mencapai 43\% (We are social, 2018). Instagram juga dipilih karena masyarakat Indonesia saat ini banyak yang menggunakan Instagram hal ini didukung dari gambar grafik penggunaan media sosial yang dikonsumsi oleh masyarakat Indonesia pada periode November 2017-November 2018 http://gs.statcounter.com/, diakses pada tanggal 1 Desember 2018 pukul 9.00 WIB) menunjukkan penggunaan media sosial Instagram mengalami kenaikan terus menerus setiap bulannya. Sehingga media sosial Youtube dan Instagram sangat efektif sebagai media untuk berbagai informasi saat ini.

Media sosial yang digunakan oleh komunitas budaya Banyumasan memiliki kegunaannya masing-masing. Youtube digunakan oleh komunitas budaya Banyumasan untuk berbagi video yang memiliki durasi panjang. Sedangkan instagram digunakan untuk berbagi video dengan durasi pendek, promosi video yang ada di youtube dan juga bisnis seperti paid promote dan endorse.

Target audiens dari komunitas budaya Banyumasan adalah wong Banyumasan yaitu masyarakat yang tinggal atau pernah tinggal di wilayah Barlingmascakeb yang meliputi Banjarnegara, Purbalingga, Banyumas, Cilacap dan Kebumen dan juga keturunan wong Banyumasan asli. Namun karena penyebarannya melalui media sosial tak jarang masyarakat dari daerah lain juga ikut melihat dan menikmati hasil karya dari komunitas budaya Banyumasan di media sosial. Untuk itu, dalam video konten yang dibuat selalu diberikan subtittle agar masyarakat umum dapat memahami video yang dibuat oleh komunitas budaya Banyumasan di media sosial.

Akun media sosial dibuat dengan menarik dan dapat mudah diingat oleh target audiens. Komunitas budaya Banyumasan membuat nama akun media sosial yang menunjukan identitas nya sebagai anggota masyarakat Banyumasan. Seperti akronim Koplak yaitu Kumpulan Orang Purwokerto Lucu dan Kreatif dan Niki Kula yang memiliki arti ini saya dalam bahasa Indonesia.

\section{b. Konten dialek ngapak}

Identitas budaya Banyumasan dikembangkan oleh komunitas budaya Banyumasan di media sosial melalui dialek ngapak. Penggunaan dialek ngapak dipilih selain karena target audiens yang merupakan masyarakat Banyumasan sehingga konten video dapat dipahami dengan baik karena menggunakan bahasa asal daerah yang biasa digunakan dalam keseharian, dialek ngapak dipilih karena unik dan memiliki karakter lucu. Penggunaan dialek ngapak oleh komunitas budaya Banyumasan bukan hanya ada di konten video yang mereka buat tetapi juga ada di penulisan caption dan sebagai bahasa yang digunakan dalam berinteraksi oleh masyarakat Banyumasan di kolom komentar.

Tema yang dipilih oleh komunitas budaya Banyumasan adalah komedi. Hal ini karena dekat dengan personal mereka juga yang suka bercanda dan merupakan karakter dari budaya Banyumasan yang cablaka dan mbanyol. Selain itu, tema komedi dipilih 
karena komunitas budaya Banyumasan ingin membuat konten berupa hiburan bagi pengguna media sosial.

\section{SIMPULAN}

Merujuk pada hasil penelitian, peneliti menyimpulkan bahwa: (1) komunitas Banyumasan dalam menggunakan simbol dialek ngapak yang merupakan identitas budaya Banyumasan dalam interaksi di media sosial merupakan pengembangan dari pemikiran atau persepsi mereka mengenai stereotype yang ada terhadap dialek ngapak dan dialek ngapak itu sendiri. Pemikiran komunitas budaya Banyumasan terhadap simbol dialek ngapak yang merupakan identitas budaya Banyumasan yaitu unik, keren, dan kaya sehingga jangan malu dan berbanggalah karena dialek ngapak memiliki potensi jika dikembangkan sebagai identitas diri. Komunitas budaya Banyumasan merefleksikan identitas budaya Banyumasan yaitu dialek ngapak melalui konten di media sosial. Refleksi tersebut merupakan karakter dari wong Banyumasan yaitu cablaka dan mbanyol. Cablaka adalah apa adanya dan mbayol adalah bertingkah konyol atau lucu. Komunitas budaya Banyumasan memilih menonjolkan karakteristik tersebut karena pada dasarnya dialek ngapak sendiri juga sudah memiliki karakter lucu. Komunitas budaya Banyumasan membangun jejaring hubungan sosial komunitas Banyumasan di media sosial. Penggunaan media sosial oleh komunitas Budaya Banyumasan berdasarkan fungsi komunikasi massa digunakan untuk menghibur, memotivasi, memajukan budaya dan integrasi masyarakat Banyumasan melalui dialek ngapak; (2) dalam mengelola akun media sosial untuk membangun identitas budaya Banyumasan melalui dialek ngapak, Komunitas budaya Banyumasan melalukan beberapa hal, yaitu : (a) Komunitas budaya Banyumasan memilih media sosial Instagram dan Youtube; (b) Target audiens dari media sosial mereka adalah masyarakat Banyumasan; (c) Menggunakan nama media sosial yang merepresentasikan identitas budaya Banyumasan; (d) Menggunakan dialek ngapak sebagai bahasa dalam konten tetapi tetap mencantumkan subtittlebahasa
Indonesia dalam video agar masyarakat budaya lain dapat memahami isi video; (e) Mengangkat komedi sebagai tema karena karakteristik dialek ngapak yang lucu dan hiburan bagi masyarakat, dan (f) Menggunakan tagar agar mudah dalam pencarian.

\section{DAFTAR RUJUKAN}

Anwar, K. (1990). Fungsi dan Peranan Bahasa. Yogyakarta: UGM Press.

Badan Informasi Geospasial. (2018). Rujukan Nasional Data Kewilayahan: Luas NKRI 8,3 Juta Kilometer Persegi. Jakarta: Badan Informasi Geospasial. Diakses pada tanggal 4 Desember 2018, dari http://www.big.go.id/beritasurta/show/rujukan-nasional-datakewilayahan-luas-nkri-8-3-jutakilometer-persegi.

Badan Pusat Statistik. (2018). Mengulik data suku di Indonesia. Diakses dari: https://www.bps.go.id/news/2015/11 $/ 18 / 127 /$ mengulik-data-suku-diindonesia.html $+\& \mathrm{~cd}=3 \& \mathrm{hl}=$ en $\& \mathrm{ct}=\mathrm{cl}$ $\mathrm{nk} \& \mathrm{gl}=\mathrm{id}$

Chaer, A. (1994). Linguistik Umum. Jakarta: PT. Rineka Cipta.

Darmastuti, R. (2013). Mindfullness Dalam Komunikasi Antarbudaya. Yogyakarta: Buku Litera.

Ghony, M. D., \& Almanshur, F. (2012). Metodologi penelitian kualitatif. Jogjakarta: Ar-Ruzz Media.

Herusatoto, B. (2008). Banyumas: Sejarah, Budaya, Bahasa dan Ngapak. Yogyakarta: LKIS.

Khotimah, S. K. (2017). Konstruksi identitas kultural "wong ngapak" melalui konsumsi media dialek banyumasan. Studi Budaya Nusantara, 1(2), 126-134.

Koentjaraningrat. (1979). Pengantar Ilmu Antropologi. Jakarta : Penerbit Aksara Baru

Liliweri, A. (2002). Makna Budaya dalam Komunikasi Antarbudaya. Yogyakarta: PT. LKiS Pelangi Aksara. 
Jurnal Pendidikan Bahasa dan Sastra, Volume 19, Nomor 2, Oktober 2019, pp. 255-266

Nasrullah, R. (2015). Media Sosial: Perspektif Komunikasi, Budaya, dan Sosioteknologi. Bandung: Simbiosa Rekatama Media.

Puntoadi, D. (2011). Menciptakan Penjualan Melalui Social Media. Jakarta: PT Elex Komputindo.

Putra, D.K.S. (2016). Komunikasi Lintas Budaya: Memahami Teks Komunikasi, Media, Agama, Dan Kebudayaan Indonesia. Bandung: PT. Remaja Rosdakarya.

Santosa, E. (2015). Identitas Lokal Dalam Media Sosial (Studi Pada Habitus, Modal, Ranah dan Praktik Kebahasaan Orang Banyumas di Media Sosial). Disertasi. Jakarta: Universitas Indonesia.
Sugiyono, P. (2015). Metode penelitian kombinasi (mixed methods). Bandung: Alfabeta.

Trianton, T. (2013). Identitas Wong Banyumas. Yogyakarta: Graha Ilmu.

We are social. (2018). Essential Insights Into Internet, Social Media, Mobile, and ECommerce Use Around The World. New York: We are social. Diakses pada tanggal 1 Desember 2018, dari https://wearesocial.com/

http://instagram.com, diakses pada tanggal 2 Desember pukul 10.13 WIB

http://youtube.com, diakses pada tanggal 3 Desember 2018 pukul 20.00 WIB

http://gs.statcounter.com/diakses pada tanggal 1 Desember 2018 pukul 9.00 WIB. 